\title{
Forecasting of Technology Development of the Arctic Hydrocarbon Resources' Extraction
}

\author{
Tatiana Chvileva* \\ Saint-Petersburg Mining University, Economy Department, 199106, 2, 21st Line, St Petersburg, Russia
}

\begin{abstract}
The Arctic region has a great potential in development of hydrocarbon resources and can play an important role in meeting future global energy needs. In the presented work the specific features of the Arctic hydrocarbon projects are identified. Key needs of oil and gas industry in technology development within the framework of projects of extraction of hydrocarbon resources in the Arctic are revealed. A critical analysis of technological forecasting methods is presented. Problems and prospects of their use in the conditions of the Arctic zones are established. The need for an integrated approach to forecasting the development of industrial systems of the Arctic zone is justified. Keywords: hydrocarbon resources, Arctic, technology, technological forecasting, forecasting methods
\end{abstract}

\section{Introduction}

According to the Organization of the Petroleum Exporting estimates the world's primary energy consumption by 2040 will increased by $40-60 \%$ compared with 2010. Thus, primary energy consumption will be 100.7 and 90.3 million barrels of oil equivalent per day for oil and natural gas, respectively, against 90.1 and 65.5 million barrels of oil equivalent per day in 2018 . At the same time, oil will continue to play an integral role in the global energy balance - the share of oil 25$27 \%$. Natural gas is expected to become the secondlargest energy source, reaching a share of $25 \%$ in the total primary energy mix in 2040 [1].

In accordance with analytical report of the US Geological Survey, the Arctic region have high potential in oil and gas production. About 30\% of the world's undiscovered reserves of natural gas and $13 \%$ of oil are concentrated in the region mostly offshore [2]. As reported by the National Petroleum Council, the potential hydrocarbon resources of the Arctic region are estimated at 525 billion barrels of oil equivalent (99 billion barrels of them are explored and 426 are unexplored) [3].

In consideration of indicated trend and high resource potential of the Arctic, oil and gas projects of this region can meet global energy demand in the long term [4].

The Arctic region is poorly studied and underdeveloped. Among the overarching factors restraining the development of the Arctic, the following should be highlighted:

- high capital investment of Arctic geologic exploration and hydrocarbon production projects;

- high prime cost level of Arctic oil, which makes it uncompetitive in the context of relatively low oil prices;
- extreme environmental conditions of the Arctic region;

- extremely high environmental sensitivity of the Arctic to any anthropogenic impact;

- deficiency of special technologies for hydrocarbon extraction in the Arctic;

- insufficient of qualified human resources for of Arctic projects implementation;

- focal formation of industrial development of the Arctic zone;

- $\quad$ underpopulation, absence of infrastructure;

- the need to take into account the interests of many parties involved in the development of the Arctic zone, as well as the need to consolidate the resources of these participants (including financial resources) for the successful implementation of the project.

The singularity of the Arctic region, its complexity and vulnerability determine the need for the application of advanced technologies in the development of hydrocarbon deposits that ensure high efficiency of the work, as well as their environmental safety.

In such conditions, issues of technological forecasting of the development of industrial systems in the Arctic region are very relevant.

In spite of the presence of quite a number of technological forecasting methods, the important issue is the choice of the most effective tools, taking into account the studied object characteristics and the conditions for the development of the forecast.

\section{Literature review}

The world scientific community shows a considerable interest to problems of development of the Arctic territories. There are a lot of studies on the Arctic. The 
huge resource potential of the region was marked by the report of the US Geological Survey in 2000 [5, 6].

The geographical spread of geological reserves between countries is analyzed in [7]. In particular, the Russian Federation owns $41 \%$ of the Arctic oil resources, Alaska is in the second place with a share of 28\%. Greenland has $18 \%$, Canada $9 \%$ and Norway $4 \%$.

In natural gas Russia also dominates (70\%), Alaska with the share of $14 \%$ is in the second place.

In the National Petroleum Council report [8] in addition to analysis of hydrocarbon reserves and degree of their geological certainty, issues of the possibility of production in the Arctic region are also considered, taking into account technological, logistic, environmental and other aspects.

Researchers involved in the development of hydrocarbon reserves in the Arctic agree that this activity is accompanied by a high level of risks, primarily environmental, and therefore requires a search for innovative methods of extraction [9, 10]. An analysis of reports and researches allows to conclude that it is necessary to develop technologies in the field of drilling and oil and gas production, taking into account difficult climatic conditions and other characteristic features of the Arctic region.

The issues of technological forecasting, its possibilities and problems began to be actively considered in the world from the middle of the 20th century, predominantly in the military sector. Subsequently, private companies recognized the effectiveness of technological forecasting tools and began to put them into practice [11].

Key researches in the field of technological forecasting belong to Ralph C. Lenz [12, 13]. He gave one of the earliest definitions of forecasting in his book «Technology Prediction». In 1962 Lenz defines technological forecasting as "the prediction of the invention, characteristics, dimensions, or performance of a machine serving some useful purpose.

Since 1960 technology forecasting methods have been developed. Detail analysis and classification of forecasting methods are presented in the works of Ralph C. Lenz, Martino, J.P., E. B. Roberts etc. [14, 15, 16]. In 1991, Stephen Millett and Edward Honton classified technology forecasting techniques as trend analyses, expert judgment, and multi-option analyses [17].

A variety of technological forecasting methods requires analysis aimed at identifying the advantages and disadvantages of each of them, as well as the conditions and possibilities for their application in practice.

Currently, technological forecasting tools are actively applied in practice in many countries of the world, especially in the USA, the United Kingdom, France, Japan. Havas A., Keenan M. [18], Johnston R., Sripaipan C. [19] presented the experience of using foresight technology in Europe and Asia.

Despite the widespread global practice of technological forecasting and the presence of a significant quantity of researches devoted to this topic, there are open questions regarding the use of appropriate tools for assessing the development of industrial systems technologies in the Arctic, which plays a fundamental role in the implementation of hydrocarbon projects in the region.

\section{Results}

The uniqueness of hydrocarbon projects implemented in the Arctic requires the use of the latest technologies. It will allow for more efficient extraction of resources and reduce the negative impact on the environment. Thus, development of technologies for the Arctic oil and gas projects is very importance, however, there are a number of factors that impede it:

- high capital intensity of technologies' research and development;

- high level of uncertainty in the Arctic hydrocarbon development projects;

- uniqueness of the hydrocarbon Arctic projects, which does not allow to use of similar technological solutions in various projects;

- extreme climatic conditions of the Arctic;

- changing of material aspects and technological requirements of projects during their implementation;

- high requirements of the world community for environmental aspects of projects implementation and applied technologies;

- low level of cooperation between the government and business in issues of technology development;

- a lack of international relations and cooperation in the field of technology development for the Arctic projects.

Factors contributing to the development of technologies for the Arctic hydrocarbon projects include the following:

- high resource potential of the Arctic region;

- exhaustibility of hydrocarbon resources in the regions of traditional production;

- government support for the development of the Arctic territories.

The hydrocarbon resources of the Arctic have a number of specific features that determine by technological complexity of developing oil and gas fields, as well as the uniqueness and vulnerability of the Arctic region.

Among the main features of such projects the following should be highlighted:

- uniqueness of each project;

- low level of knowledge of the region and the Arctic hydrocarbon reserves;

- high environmental risks with low knowledge of the consequences of possible oil spills;

- the virtual absence of infrastructure and appropriate support structures in the region;

- the virtual absence of commercially proven technologies for the development of the Arctic shelf beyond shallow coastal waters.

The listed features determine the high uncertainty of the implementation of oil and gas projects in the Arctic. It complicates the process of technological forecasting.

As part of the implementation of technological forecasting in the Arctic, it is advisable to make forecasts in two directions: 
- prospects for the development of oil and natural gas production technologies in extreme climatic conditions and on the shelf;

- prospects for the development of technologies for the needs of socio-economic systems and industrial complexes of the Arctic, affecting the activities of oil and gas companies.

Key needs of oil and gas industry in technology development within the framework of hydrocarbon extraction projects in the Arctic are presented in table 1.

Table 1. Key needs of oil and gas industry in technology development within the framework of hydrocarbon extraction projects in the Arctic

\begin{tabular}{|c|c|}
\hline $\begin{array}{c}\text { Direction of } \\
\text { Technology } \\
\text { Development }\end{array}$ & Required technology \\
\hline $\begin{array}{l}\text { Drilling and } \\
\text { production of oil } \\
\text { and natural gas }\end{array}$ & $\begin{array}{l}\text { - development of drilling } \\
\text { technologies in the conditions of } \\
\text { permafrost; } \\
\text { - development of floating drilling } \\
\text { platforms capable of working in } \\
\text { cold waters; } \\
\text { - development of technology for } \\
\text { protection floating drilling } \\
\text { platforms from collisions with } \\
\text { ice; } \\
\text { - development of technology of } \\
\text { inclined and horizontal drilling } \\
\text { from the shore. }\end{array}$ \\
\hline $\begin{array}{l}\text { Environmental } \\
\text { safety }\end{array}$ & $\begin{array}{l}\text { - development of technologies for } \\
\text { preventing oil spills within the } \\
\text { framework of projects of } \\
\text { extraction of hydrocarbon } \\
\text { resources in the Arctic; } \\
\text { - development of oil spill } \\
\text { response technologies in the } \\
\text { Arctic; } \\
\text { - development of zero discharge } \\
\text { oil platforms; } \\
\text { - development of technologies for } \\
\text { environmental monitoring in the } \\
\text { Arctic zone. }\end{array}$ \\
\hline
\end{tabular}

Existing methods of technological forecasting are divided into 3 groups: statistical methods, expert judgment, and multi-option analyses methods based on numerical data and expert methods. Statistical methods based on the processing of numerical data extrapolates historical trends in the future. Expert methods of forecasting can also be based on past data, but use a subjective assessment of experts as a source of information [20].

One of the most significant things is to decide the right assumptions and appropriate methods to a given situation, so as to predict the right technological change, since technology forecasting results are inevitably affected by the methods employed.

Analysis of existing methods of technological forecasting from the point of view of possibility of their application for the foresight of technology development in conditions of the Arctic region is presented in table 2.
As a result of a comparative analysis of technological forecasting methods, the following conclusions can be drawn:

- for prediction of the development of technologies for extraction of hydrocarbon resources in the Arctic it is necessary to adapt an existing foresight methods and tools;

- in order to improve the quality of technology development forecasts, several methods must be applied simultaneously;

- the uniqueness of projects of extraction of hydrocarbon reserves in the Arctic determines the impossibility of using of analogy methods and forecasting methods based on the analysis of historical data of past periods;

- expert methods can be used to predict the development of technologies for the extraction of hydrocarbon resources in the Arctic, however, they require careful preliminary preparation;

- forecasts obtained by using various methods must be compared with each other in order to determine discrepancies with the subsequent identification and analysis of the causes of this discrepancy.

\section{Conclusion}

The Arctic region has a great potential in extraction of hydrocarbon resources and can play an important role in meeting future global energy needs. The projects of extraction of hydrocarbon resources in the Arctic have a number of specific features, which make it difficult to forecast technology development.

Poor experience of extraction of oil and gas resources in the region does not allow to build a statistical database for the application of forecasting methods based on numerical data.

Improving the quality of technological forecasting of the development of industrial systems in the Arctic can be achieved through the use of a set of methods based on expert assessments.

As a result of the study, it can be concluded that the key methods for generating long-term and short-term forecasts for the development of technologies used in the process of hydrocarbon resources' extraction in the Arctic are following: Delphi, scenario planning, cross impact analysis, system Dynamics method.

The differences in the forecasts obtained using different tools should be analyzed to identify the causes of such deviations. This will contribute to a deeper understanding of the problems and trends in the development of technologies for the oil and gas sector as part of developing the resource base of the Arctic region. 
Table 2 .Analysis of existing methods of technological forecasting from the point of view of the possibility of their application for the conditions of the Arctic region

\begin{tabular}{|c|c|c|}
\hline $\begin{array}{l}\text { Forecasting } \\
\text { method }\end{array}$ & Method contents & Evaluation of the possibility of using the method \\
\hline Delphi & $\begin{array}{l}\text { The method entails a group of } \\
\text { experts who anonymously reply } \\
\text { to questionnaires and } \\
\text { subsequently receive feedback in } \\
\text { the form of a statistical } \\
\text { representation of the "group } \\
\text { response," after which the process } \\
\text { repeats itself. }\end{array}$ & $\begin{array}{l}\text { The method can be successfully applied for forecasting the } \\
\text { development of technologies for the extraction of the Arctic } \\
\text { hydrocarbon deposits. The Delphi method allow to forecast the } \\
\text { likelihood of realizing uncertain future technology, the probable } \\
\text { development date, desirability, etc. } \\
\text { Composition of experts, their competence, as well as the } \\
\text { correctness of questionnaires have a strong influence on the } \\
\text { quality of the generated forecast. } \\
\text { The weaknesses of the Delphi method are the following: } \\
\text { relatively expensive; complication of selecting experts; biases } \\
\text { of expert decisions; selection of participants and the preparation } \\
\text { of corrective questionnaires. }\end{array}$ \\
\hline $\begin{array}{l}\text { Scenario } \\
\text { planning }\end{array}$ & $\begin{array}{l}\text { Scenario planning is an approach } \\
\text { to create alternative scenarios } \\
\text { about many plausible futures in } \\
\text { complex and uncertain business } \\
\text { environments. }\end{array}$ & $\begin{array}{l}\text { The use of the scenario method can improve the quality of } \\
\text { forecasts due to the possibility of taking into account alternative } \\
\text { options for the development of the external and internal } \\
\text { environment of hydrocarbon projects in the Arctic and social- } \\
\text { economic system. } \\
\text { The method allows to design various scenarios of development } \\
\text { of technologies and industrial systems in the Arctic, indicating } \\
\text { their probabilistic assessment. }\end{array}$ \\
\hline $\begin{array}{l}\text { Cross impact } \\
\text { analysis }\end{array}$ & $\begin{array}{l}\text { Cross impact analysis allows to } \\
\text { evaluate changes in the } \\
\text { probability of the occurrence of a } \\
\text { given set of events consequent on } \\
\text { the actual occurrence of one of } \\
\text { them. }\end{array}$ & $\begin{array}{l}\text { The use of cross-impact analysis is a great importance in } \\
\text { predicting the development of technologies in the extraction of } \\
\text { the Arctic hydrocarbon deposits. It allows to make a } \\
\text { comprehensive assessment of the consequences of managerial } \\
\text { and technological decisions on a vulnerable ecosystem in the } \\
\text { region. }\end{array}$ \\
\hline $\begin{array}{l}\text { System } \\
\text { Dynamics } \\
\text { method }\end{array}$ & $\begin{array}{l}\text { System Dynamics is an analytical } \\
\text { approach to analyze dynamic } \\
\text { behavior of complex social } \\
\text { systems and to understand how } \\
\text { things change over time. }\end{array}$ & $\begin{array}{l}\text { Despite the low capabilities of the system dynamics method in } \\
\text { the field of technology forecasting, its application allows to } \\
\text { determine the future state and problems of social systems in the } \\
\text { Arctic region and their technology needs. }\end{array}$ \\
\hline $\begin{array}{l}\text { Trend } \\
\text { Extrapolation }\end{array}$ & $\begin{array}{l}\text { Trend Extrapolation is statistical } \\
\text { method to project the future } \\
\text { pattern on the base of past } \\
\text { indicators. }\end{array}$ & $\begin{array}{l}\text { Widely used in the framework of economic forecasts for the } \\
\text { short term. This tool must be used carefully, for the past is an } \\
\text { indication of the future only when the environmental structure } \\
\text { of the past remains constant in the future. Capacity to use trend } \\
\text { extrapolation methods for forecasting the development of the } \\
\text { Arctic oil fields extraction technologies is limited because of } \\
\text { unique features of the Arctic projects. }\end{array}$ \\
\hline $\begin{array}{l}\text { Technological } \\
\text { forecasting } \\
\text { data } \\
\text { envelopment } \\
\text { analysis, } \\
\text { (TFDEA) } \\
\end{array}$ & $\begin{array}{l}\text { TFDEA is to measure the } \\
\text { technological rate of change in } \\
\text { order to forecast future } \\
\text { technological advance. }\end{array}$ & $\begin{array}{l}\text { TFDEA has been the employment of a constant rate of } \\
\text { technological change. This rate is identified on the basis of } \\
\text { historical data. However, accepting a constant change rate is } \\
\text { somehow contrasting with the nature of technological change } \\
\text { and may fail to forecast properly in long-run. }\end{array}$ \\
\hline Data Mining & $\begin{array}{l}\text { Data Mining is the process of } \\
\text { discovering patterns in } \\
\text { large data sets involving methods } \\
\text { at the intersection of machine } \\
\text { learning, statistics and database } \\
\text { systems. }\end{array}$ & $\begin{array}{l}\text { The application of the Data Mining method is difficult due to } \\
\text { the lack of backdata owing to the small number of the Arctic } \\
\text { projects and the uniqueness of each of them. }\end{array}$ \\
\hline Analogies & $\begin{array}{l}\text { Analogy method allow to predict } \\
\text { possible futures by systematic } \\
\text { comparison of the technology } \\
\text { with similar one by looking at } \\
\text { historical data }\end{array}$ & $\begin{array}{l}\text { The application of the analogy method is difficult due to the } \\
\text { small number of the Arctic projects and the uniqueness of each } \\
\text { of them. }\end{array}$ \\
\hline
\end{tabular}


ACKNOWLEDGEMENTS The study was financially supported by the Russian Foundation for Basic Research (RFBR), Project No. 18-010-00734 "Evolution of methodology of technological forecasting of development of the interconnected industrial and social and economic systems at hydrocarbon resources development in the Arctic”.

\section{References}

1. Organization of the Petroleum Exporting 2019 Countries World Oil Outlook 2040. https://woo.opec.org/chapter.php?chapterNr=12

2. D. Gautier et al. Science, 324, 1175 (2009).

3. Realizing the Promise of U.S. Arctic Oil and Gas Resources. http://www.npcarcticpotentialreport.org/pdf/AR_Ex ec_Summary.pdf

4. A.E. Cherepovitsyn, N.V. Romasheva, T.A. Chvileva, IJCET, 9, 938 (2018).

5. USGS. Final Report: Oil and Gas Resource Assessment of the Russian Arctic (United States Geological Survey, 2008).

6. USGS. World Petroleum Assessment (United States Geological Survey, 2000).

7. Lindholt L., Glomsrød S. The role of the Arctic in future global petroleum supply. https://www.ssb.no/a/publikasjoner/pdf/DP/dp645.p df

8. National Petroleum Council Arctic Potential Realizing the Promise of U.S. Arctic Oil and Gas Resources. https://www.npc.org/2019-Arctic_SALoRes.pdf

9. The Risks and Potential Impacts of Oil Exploration in The Arctic. https://www.greenpeace.de/sites/www.greenpeace.d e/files/oel-papier_gp_uk_0.pdf

10. Eurasia Group report. Challenges And Opportunities Of Oil And Gas Investment In The Arctic. Wilson Center https://www.wilsoncenter.org/sites/default/files/Arti c\%20Report_F2.pdf
11. Cho Yonghee, Tugrul U. Daim, Research and Technology Management in the Electricity Industry: Methods, Tools and Case Studies (Green Energy and Technology) (Springer, 2013).

12. M. J. Cetron, Technological forecasting: a practical approach (Technology Forecasting Institute, 1969).

13. R. C. Lenz, Rates of adaptation/ substitution in technological change (Austin. TX, Technology Futures, Inc., 1985)

14. E. Jantsch, Technological Forecasting In Perspective: A Framework for Technological Forecasting, its Techniques and Organization (OCED,1967).

15. E.B. Roberts, Exploratory and normative technological forecasting: a critical appraisal, Technological forecasting, 1, 113, 1969.

16. J.P. Martino, Technological forecasting for decision making (New York: North-Holland, 1983).

17. S. M. Millett, E. J. Honton, A Manager’s Guide to Technology Forecasting and Strategy Analysis Methods. (Battelle Press, 1991).

18. Havas A., Keenan M. Foresight in the Countries of Central and Eastern Europe (Cheltenham: Edward Elgar, 2008).

19. Johnston R., Sripaipan C. Foresight in Industrialising Asia (Cheltenham: Edward Elgar, 2008).

20. N.N. Zelenov, Modernization. Innovation Development, 9, 32 (2012) 